\title{
A SZAKMAI ELKÖTELEZETTSÉG ÉS A MUNKAHELYRŐL VALÓ KILÉPÉSI SZÁNDÉK ÖSSZEFÜGGÉSEI AZ ÉLETPÁLYA ELŐREHALADTÁVAL
}

\author{
KOLTÓI LILLA - KISS PASZKÁL \\ Károli Gáspár Református Egyetem, BTK Pszichológiai Intézet \\ E-mail: koltoi.lilla@kre.hu \\ Benyújtva: 2020. május 18. - Elfogadva: 2020. december 10.
}

Háttér: A mai karrierutakra a töredezettség, szekvenciák sora jellemzó, ami együtt jár a szakmai célok, attitüdök és az identitás újrafogalmazásával (Wehmeyer és mtsai, 2019; Ashforth és Saks, 1995). Másrészt a szakmai identitás, a szakmával való azonosulás hosszú távú, stabilabb tényezô (Colarelli és Bishop, 1990), kevésbé hat rá negatívan a munkahelyváltás, ha az egyén nem pályaelhagyó.

Cél: Kutatásunkban az idôi tényezók tükrében vizsgáljuk a szakmához és a munkatevékenységhez való viszonyulást. Arra keressük a választ, hogy az életkor, a szakmában és a munkahelyen eltöltött idô mennyire határozza meg a pálya alakulása szempontjából fontos tényezóket, a szakmai elkötelezettséget, a munkába való bevonódást, a szubjektív pályasikerességet, és ezek együtt milyen kapcsolatban vannak a munkahelyról való kilépési szándékkal.

Módszer: Az online kutatásban $(N=1172)$ állandó munkaviszonnyal rendelkezố munkavállalók vettek részt. A változók közötti összefüggéseket egy útmodell segitségével, valamint a korcsoportok összehasonlításával ellenôriztük.

Eredmények: Az eredmények alapján az mondható, hogy a kilépési szándékot az idôi tényezôk nem befolyásolják közvetlenül, csak más tényezókön (a munkába való bevonódás, szakmai elkötelezettség, szubjektív pályasikeresség) keresztül, míg a szakmai elkötelezettséget és a munkába való bevonódást befolyásolja a szakmában eltöltött idô és az életkor. A korcsoportok összehasonlítása arra mutat rá, hogy az életkorral növekszik a bevonódás és elkötelezettség mértéke, ugyanakkor a kilépési szándék csak a negyvenes korosztályig mutat csökkenô tendenciát, a legidôsebb korosztálynál a harmincasok szintjére emelkedik ez az érték.

Kulcsszavak: kilépési szándék, szakmai elkötelezettség, munkába való bevonódás, szociális identitás elmélete 


\section{BEVEZETÉS}

A digitális technológiai fejlôdés, a mai munkaerôpiaci változások, valamint a munkavállalók motivációinak és attitúdjeinek megváltozása (Twenge, Campbell, Hoffman és Lance, 2010) felveti a kérdést, mennyire van szerepe az idônek a szakmai és munkahelyi sikeresség alakulásában, a szakmában és a munkahelyen eltöltött idô elôsegíti-e a szakmához és a munkatevékenységhez való pozitív viszonyulást, csökkenti-e a munkahelyről való kilépés arányát. Ez különösen azért lényeges, mert a fiatalabb korosztályhoz tartozó munkavállalók esetében valószínúsíthetôk a gyakoribb munkahelyváltások és pályamódosítások, egy új karrierút elindítása az újbóli beilleszkedéssel, megszilárdítással (Sullivan és Crocitto, 2007), az identitás újrafogalmazásával. Ez a szemlélet kevésbé egységes, inkább töredezett, szekvenciákból álló karrierutat valószínúsít, ami megnehezítheti a hosszabb távú és mélyebb elkötelezôdést akár a szakmát, akár a szervezetet tekintjük. A pályafejlốdésnek vannak olyan lényeges elemei, amelyek alakulásában, fejlődésében fontos szempont a linearitás. Ilyen a szakmához való viszonyulás pályaszakaszokon és munkahelyeken átívelô, viszonylagos állandóságot mutató tényezôje (n.b. a szakmai identitás újabb elméleteiben már hangsúlyos az identitás változása, pl. Ibarra, 1999), azaz a szakmai identitás, elkötelezettség alakulásában meghatározó a folytonosság, a hosszabb távú perspektíva. Kutatásunkban a szociális identitás elméleti keretében azt a kérdést járjuk körül, hogy az idô mint folytonosság milyen szerepet játszik a szakmához való pozitív viszonyulás alakulásában, valamint hogyan kapcsolódik a sikerességérzethez és a váltáshoz, ami a kutatásunkban a munkahelyrốl való kilépést jelenti.

\section{A SZELFHEZ VALÓ VISZONY AZ ÉLETPÁLYA TÜKRÉBEN}

Az egyén önmagáról való tudása és vélekedései alapvetôen meghatározzák az életpályáját. Ezért a szakmai szelf szerepe a pálya alakulásában számos korábbi és újabb pályafejlôdési elméletben megjelenik, bár többnyire impliciten (Blustein, 2013), az idô múlásával a szakmai énünk stabilizálódik és kikristályosodik. Azt hozzá kell tenni, hogy a karrier- és pályaelméletek területén nem egységes a szakmai szelf konceptualizálása, különbözô konstruktumokban jelenik meg. Jellemzô, hogy számos, a szelfelméletekben gyökerezó fogalmat használnak hasonló értelemben az egyén szakmájához való viszonyulásának megragadásához, pl. énfogalom (Super, 1980), pályaidentitás (Holland, 1997; Ritoók, 2008), provizionális szelfek (Ibarra, 1999). Azonban az vitathatatlan, és ez a fogalmi sokszínúség is azt mutatja, hogy a pályafejlôdés szempontjából lényeges a szakmai szelf alakulása, mely több pályaelméletben is hangsúlyt kap.

Mivel az énkoncepció, az identitás viszonylagos stabilitást mutat az idốben, a fejlôdését hajlamosak vagyunk lineárisnak látni a kialakulástól a letisztulásig, mely folyamat során az identitás csiszolódik, de nagy és sok változásról nem igazán beszélünk. Ez a felfogás tükröződik Holland személyiségtipológiai elméletében, amely szerint a pályaidentitás ,az egyén céljairól, érdeklôdésérôl, képességeirôl alkotott letisztult, stabil képe" (Holland, 1997, idézi Nauta, 2013, 63.). Holland értelmezésében a konzisztencia, a változások kis mértéke járul hozzá a letisztult, stabil identitáshoz, a gyakori és nagy változások diffúz identitáshoz vezethetnek (Nauta, 2013). 
Ritoók Magda (2008) pályaidentifikációról alkotott felfogásában a pályaazonosulás dinamikus folyamata kerül a fókuszba. Meghatározásában a pályaidentifikáció a „pálya követelményrendszere és a munkát végzô ember domináló személyiségjegyei közötti megfelelés minôségének a mutatója, az életpálya és a személyiség fejlôdési folyamatának a dinamikus tükrözője” (Ritoók, 2008, 16.). A pályaazonosulás alapfeltételének a pálya adta élménytartalom és az egyén élményigényének a megegyezését tartja. Longitudinális, 40 évet átfogó pályakövetéses kutatásának egyik fontos eredménye, hogy a sikerességet leginkább a személyiségjegyek határozzák meg. A pályaazonosulást jelentôs mértékben a társas támogatottság befolyásolja.

A pályafejlốdési elméletek a karriert egy életen át tartó folyamatként írják le, ami a gyerekkorban kezdődik, és a nyugdíjba vonulással ér véget, közben munkával kapcsolatos és munkán kívüli események-élmények folyama alakítja a fejlődési irányt (Patton és McMahon, 2014; Lent és Brown, 2013). Ebbe a körbe sorolják Super (1980) nagy hatású életpályamodelljét, amely a pályafejlődés négy szakaszát írja le a növekedéstôl a hanyatlásig. Ebben nagy hangsúlyt kap az egyén önmeghatározása. Elméletében az egyén énkoncepciója az egyik kulcselem, amely a megszilárdulás szakaszában stabilizálódik, és a negyvenes éveire alakul ki stabilan és tartósan. Super megfogalmazásában az énfogalom „az egyén képe önmagáról egy-egy szerepben, szituációban, pozíciókban, valamilyen funkció ellátásában vagy kapcsolatok hálójában” (Super, 1963, idézi Hartung, 2013, 88.). Az énfogalomnak egyik meghatározó része a munka területére kialakított énfogalom (Gibson, 2003). Ehhez az is hozzátartozik, mennyire fontos része a munka vagy szakma az egyén énmeghatározásának (Lent és Brown, 2013). A modell egyébként kiváló elméleti keretét adja a karrier mint élethosszig tartó folyamat megközelítésnek. Az egyén különbözô változásokon megy át élete során, különbözó életkori feladatokat teljesít az egyes életkori szakaszokban, ami viszont alakítja az énfogalmát, formálja az identitását (Patton és McMahon, 2014; Hartung, 2013).

A mai bizonytalanabb és kiszámíthatatlanabb gazdasági környezetben az egyén pályáját nem lehet egy életre szóló elkötelezôdésként tekinteni, hanem inkább úgy, hogy a munkavállaló „eladja” szolgáltatásként tudását és képességeit a munkaadónak, aki a projektet szervezi (Savickas, 2012). A karrierutat ezért az újabb elméletekben a szekvenciális, töredezettebb időszemlélet jellemzi, a pálya feladatok és tapasztalatok sorozataként írható le. Eszerint a munkavállalók nagy része átéli a váltás folyamatát, ami a célok, attitûdök és az identitás újrafogalmazásával jár együtt. A váltás megélése (akár szakmáról, akár pozícióról, munkakörrôl beszélünk) nemcsak a munka hatékonyságát, hanem az egyén jóllétét is befolyásolja a maga nehézségeivel (Ashforth és Saks, 1995). Másrészt viszont a pályamódosítás része lehet a személyes fejlôdésnek, hiszen egy új munka jobban megfelelhet az érettebb szelffel rendelkezó egyénnek.

Az újabb elméletek és modellek közül kiemelkedik a Savickas fémjelezte pályaépitési elmélet (Career Construction Theory), amely Super életpálya-elméletének egyfajta felfrissítése a szociális konstruktivizmus elméleti keretében (Wehmeyer és mtsai, 2019), és Savickas maga is elismeri elméletének hasonlóságát James 1890-es szelfelméletével (Yates, 2017). Super fejlôdési szemléletét a kiszámítható pályaszakaszokkal, az egyén érésével felváltotta egy új, melynek fókuszában az egyénnek a változó környezethez való alkalmazkodása áll. Az idô az egyén narratíváiban, a pályafutásáról, munkával töltött életérôl szóló történeteiben kap szerepet, amelyet az egyén mesél a munkával 
töltött életéról (Savickas, 2013). Mivel már nincs jól tervezhetô, szervezet által is megtámogatott karrierút, az egyén feladata ennek építése, ezáltal a szelfjének, énfogalmának megkonstruálása (Savickas, 2013). Az egyén a döntéseivel, amelyek tükrözik az énfogalmát, konstruálja a pályáját (Savickas, 2012), aminek releváns, speciális jelentéssel bíró eleme a váltás, a kilépés vagy annak szándéka.

\section{A SZAKMAI IDENTITÁS ÉS SZAKMAI ELKÖTELEZETTSÉG A SZOCIÁLIS IDENTITÁS ELMÉLETI MEGKÖZELÍTÉSÉBEN}

A pályafejlődési elméletek, ahogy fentebb is írtuk, szélesebb kontextusban élethosszig tartó folyamatként értelmezik az egyén karrierútját, amely szerepek, döntések és változások szekvenciájaként is értelmezhetô (Wehmeyer és mtsai, 2019; Savickas, 2012; Twenge és mtsai, 2010). Ezen belül, ha a szakmához való viszonyra fókuszálunk, akkor egy egységesebb perspektívájú, pályaszakaszokon átívelő, hosszabb távú viszonyulásra gondolhatunk (Colarelli és Bishop, 1990; Blau, 1985), amely az egyik kötôanyaga a karrierív szekvenciáinak.

Az egyén azzal, hogy egy szakma mellett elkötelezi magát, egy szakmai közösség tagja is lesz, azaz az egyéni fejlôdés mellett a társas tényezók fontos meghatározói a szakmai énképének. A szakmai identitás szociálpszichológiai megközelítése a szociális identitás elméletben gyökerezik.

Tajfel szociális identitás elmélete (1981) és a Turner nevéhez köthető (1987) önkategorizációs elmélet abból indul ki, hogy a különbözó szociális csoportokhoz való tartozás fontos részét képezi az egyén önmeghatározásának, a kategóriákkal való azonosulás alkotja az identitás szerkezetét (Pataki, 2004), illetve meghatározza az egyén csoporttagként való viselkedését (Deaux és mtsai, 1995; Ellemers és mtsai, 1999). Tajfel elméletén alapulva a kognitív (kategoriális tudás), affektív (a csoporthoz tartozáshoz kapcsolódó érzelmek) és értékeló (a csoporthoz való tartozás értékelése) aspektusát különítik el az identitásnak (pl. Deaux, Reid, Mizrahi és Ethier, 1995; Ellemers, Kortekaas és Ouwerkerk, 1999; Pataki, 2004). Ha a szakmát mint csoportot tekintjük, a szakmai identitásképzés kognitív komponense a szakmai identitás beépülése az egyén identitásába, vagyis egy szakmai közösség tagjaként való önkategorizáció. Az affektív komponens az adott szakmai csoport iránti elkötelezôdés, pozitív elfogultság. Az értékeló komponens nem a személyes önértékeléssel, hanem inkább a kollektív önértékeléssel áll kapcsolatban, amely Luhtanen és Crocker szerint azt mutatja, hogyan tartjuk fenn az adott szociális identitásunkat (Kiss, 2012).

Haslam és munkatársai (2008, 2009) a szociális identitás és a jóllét kapcsolatát vizsgálva azt emelték ki, hogy az egyén számára jelentôs csoport tagjának lenni biztonságés értékességérzetet ad, ami elôsegíti az elégedettség, pozitív önértékelés és sikerességérzet kialakulását. Másrészt a pozitív szociális identitás együtt jár a magasabb fokú társas támogatással, értékesség és elfogadottság érzetét keltheti az egyénben. Ennek fényében az feltételezhetô, hogy a kiforrott, pozitív szakmai identitás hozzájárul az észlelt szakmai sikerességhez, és a társas tényezôk miatt csökkentheti a szakma, de akár a munkahely elhagyásának a valószínúségét. 


\section{Szakmai elkötelezettség}

A csoporttal való azonosulás, bevonódottság mértéke határozza meg az egyén hajlandóságát a csoporttagság feltételei szerinti viselkedésre. Ebben az értelemben a szociális identitás aspektusai közül az érzelmi komponens a meghatározó, azaz a csoport iránti érzelmi elkötelezettség érzete. Ugyanahhoz a csoporthoz tartozó egyének eltérô viselkedést mutathatnak attól függően, mennyire érzik magukat elkötelezettnek a csoport irányában (Ellemers és mtsai, 1999).

A szakmai elkötelezettség az egyén saját szakmája iránti attitűdjeit jelenti, amelyek befolyásolják a viselkedését (Blau, 1985). Leírható a szakmai célokkal való azonosulásként, az ezekbe való bevonódásként is. Ezek a célok legtöbbször átívelnek munkákon, munkahelyeken, mivel a szakmai elkötelezettség hosszú távú elkötelezettséget jelent. Ez a hosszú távú perspektíva összefüggésben áll az egyén karrierjével kapcsolatos jövôképével, és ha magasabb az elkötelezettség, akkor az egyén valószínúleg jobban kitart a céljai mellett, és kevésbé valószínú, hogy pályát módosít Colarelli és Bishop szerint (1990). A szerzôk három érvet hoznak fel amellett, hogyan növeli az életkor a szakmai elkötelezettséget. Az életkor előrehaladtával az egyén egyre inkább fókuszált és stabil lesz a pályáját tekintve, másrészt egyre több idôt, energiát és egyéb erôforrásokat fektet be a karrierjébe, ami egyre jobban köti a szakmájához. Harmadrészt pedig egy adott életkor után az emberek nagy része lezárja magában az alternatív pályalehetôségeket (Colarelli és Bishop, 1990).

\section{Munkába való bevonódás}

A szakmai identitásképzés dinamikus és kölcsönhatásokon alapuló folyamat (Ibarra, 1999), amelyben az egyén és a kontextus egyaránt fontos. Brown szakmai identitásképzés dinamikus modelljében az identitás a sajátos szakmai közösségekben formálódik szocializáció, interakció és tanulás útján (Bimrose és Brown, 2019). A modell szerint az aktivitás - vagyis a munkatevékenységek, illetve az ezekbe való bevonódás - nagy szerepet játszik az identitás alakulásában. A munkatevékenységekbe való bevonódás azért lényeges az identitásképzés szempontjából, mert a hétköznapi viselkedéseken keresztül lehet megélni a szakmához való kapcsolatot (Bodnár és Takács, 2006).

A legtöbb mai, munkába való bevonódással foglalkozó kutatást érdekes módon a kiégéssel kapcsolatos vizsgálódások ihlették. Maslach és Leiter (1997) szerint a bevonódást energia, involválódás és hatékonyság jellemzi, és a kiégés esetében ez az energia kimerültséggé, az involválódás cinizmussá, a hatékonyság pedig eredménytelenséggé változik. Az egyik legújabb megközelítésben a munkába való bevonódás egy olyan munkával kapcsolatos kielégítô állapot, amelyet az erố, elkötelezettség, elmélyülés jellemez. Az erô magas energiaszintet és rezilienciát jelent a munkában, az elkötelezettség alatt involváltságot, jelentôség, lelkesedés és kihívás érzetét, míg az elmélyülés alatt egy nagyon koncentrált munkába való belefeledkezés állapotát értik (Bakker és Schaufeli, 2008). Ez az állapot magasabb teljesítménnyel és elégedettséggel jár (Luthans, Avolio, Avey és Norman, 2007). 


\section{Kilépési szándék}

A szakmával való azonosulás, a szakmai elkötelezettség csökkenti a munkahelyrốl való kilépés valószínúségét (Haslam és mtsai, 2008). Ugyanakkor a munkaerópiaci és gazdasági változások átalakították a munkavállalói attitûdöket és viselkedéseket, és egyre valószínúbb, hogy az egyén a pályája során többször vált munkahelyet vagy módosít pályát (Ferraro, Prussia és Mehrotra, 2018). A szakma- vagy munkahelyváltás szerves része az egyén fejlődésének, önkonstruálási folyamatának (Savickas, 2012). Másrészt a szervezetek számára jelentôs problémát jelenthet a munkavállalók kilépése, a nagy fluktuáció növeli az anyagi és egyéb költségeket. Ezért a kutatásokban már a szándék megjelenését, a munkahelyrốl való kilépés fontolgatását is vizsgálni kezdték, például Khapova és munkatársai (2007) azt találták, hogy a kilépési szándék (motivációs faktor) jól elôrejelzi a viselkedést, és ha jól mérik, akkor a valós viselkedés nagy varianciáját magyarázza.

Khapova és munkatársai (2007) a munkahelyrốl való kilépés szándéka három bejósló tényezőjét vizsgálták: a karrierváltozáshoz való viszonyulást, észlelt társas nyomást, valamint az észlelt viselkedési kontrollt. A karrierváltás iránti attitúdök magyarázatát a kiértékelésre építik, vagyis hogy az egyén a viselkedést (jelen esetben a szakmaváltást) mennyire kedvezôen ítéli meg. Az észlelt társas nyomás az egyén számára fontos személyek elvárásait jelenti, a család, barátok, kollégák stb. milyen elvárásokat fogalmaznak meg az egyén munkájával kapcsolatban. A harmadik tényezó, az észlelt kontroll a viselkedés felett arra vonatkozik, hogy az egyén mennyire biztos abban, hogy a viselkedést kivitelezni tudja majd. Eredményeik bizonyították ennek a három tényezônek a szerepét a kilépési szándékban. Kutatásuk nem várt meglepô eredménye a szakmai identitás szerepére hívta fel a figyelmet, miszerint a kilépési szándék bejósló változói között a szakmai identitásnak volt a legnagyobb magyarázóereje (minél kevésbé meghatározó ez az identitás, minél alacsonyabb a szakmával való azonosulás, annál valószínúbb, hogy az egyén a kilépést fontolgatja).

A fentiekhez hasonló kapcsolatot talált több kutatás a munkába való bevonódás és a munkahelyrôl való kilépés összefüggésének esetében. A munkába való bevonódás növeli a munkával való elégedettség mértékét, illetve a szervezetben való maradás szándékát, vagyis csökken a munkahelyrôl való kilépési szándék valószínúsége (Saks, 2006; Schaufeli, 2012; Schaufeli és Bakker, 2004).

Szintén gyakran vizsgált összefüggés a munkahelyrôl való kilépés szándéka és a munkával való elégedettség kapcsolata, ezek szerint a kilépési szándékot nagyban meghatározza a munkával való elégedettség mértéke, azaz minél kevésbé elégedett a munkájával az egyén, annál valószínúbb, hogy kilép a munkahelyérôl, pl. Blau és Boal, 1987; Chang, Wang és Huang, 2013; Chen, Brown, Bowers és Chang, 2015; Hartmann és Rutherford, 2015; Mowday, Steers és Porter, 1979.

\section{MÓDSZEREK}

A kutatásunk egy hosszabb kutatási folyamat elsố lépése, fókuszában a szakmai identitás, valamint vele összefüggésben a szubjektív pályasikeresség és a munkahelyrôl való 
kilépési szándék idôi vonatkozású vizsgálata áll, azaz arra voltunk kíváncsiak, mekkora hatása van az idônek ezen tényezók alakulására. Az idôi tényezóket kétféleképpen ragadtuk meg: a szakmában és a jelenlegi munkahelyen eltöltött idô változóival, illetve a korcsoportok összehasonlításával.

Az egyik kérdésfelvetésünk arra vonatkozott, hogy a szakmában eltöltött idônek a szakmában, munkahelyen megtartó szerepe van, vagy ellenkezôleg, az idô elôrehaladtával nagyobb valószínûséggel lépnek ki a munkahelyükrôl a munkavállalók, valamint gyengül a szakmájuk iránti elkötelezettség. A vizsgálatban egy modellt állítottunk fel, amelyben azt elemezzük, hogy az idôi tényezôk mennyire jósolják be a munkahelyi kilépési szándékot. Azt feltételezzük, hogy a szakmához és a munkához való viszonyulás, valamint a pályasikeresség változóin keresztül hatnak a kilépési szándékra. A másik kérdésfeltevésünk a korcsoportok közötti különbségekre vonatkozik, azaz egyes korcsoportok mennyiben mutatnak eltérést a vizsgált változókban. Valószínúsíthetô, hogy különbséget találunk a fiatalabbak és az idősebbek elkötelezettségének mértékében, illetve a kilépési szándék változójában (Katz, Rudolph és Zacher, 2019; Twenge és mtsai, 2010).

\section{Hipotézisek}

H1a: A kilépési szándék bejósló változói között szignifikáns magyarázó ereje van a szakmában eltöltött idônek és az életkornak. Ezek az idôi változók a szakmai elkötelezettségen és a munkába való bevonódáson keresztül hatnak a kilépési szándékra.

H1b: A munkába való bevonódásnak inkább közvetett, a szubjektív pályasikeresség mediáló hatásán keresztül van befolyása a kilépési szándékra, míg a szakmai elkötelezettségnek inkább közvetlen hatása van a kilépési szándékra.

H2a: Minél idôsebb az adott korcsoport, annál nagyobb a szakmai elkötelezettség, vagyis a legidôsebb korcsoportban a legerôsebb, míg a legfiatalabban a legalacsonyabb.

H2b: A munkába való bevonódás mértéke alacsonyabb a fiatalabb korcsoportoknál, mint az idôsebbeknél.

H2c: A szubjektív pályasikeresség értéke a legfiatalabb esetében alacsonyabb, mint a többi életkori csoporté.

H2d: A kilépési szándék a legfiatalabb korcsoportnál a legmagasabb, és fokozatosan csökkenve a legidósebbnél a legalacsonyabb.

\section{Eljárás}

Az online adatfelvétel 2018-2019 telén történt. A mintába kerülés kritériuma az állandó munkaviszonnyal rendelkezés és szervezetben végzett munka volt. A kérdôívcsomagot több mint 1200 fố töltötte ki, de az adattisztítás után 1172 fố válaszait tudtuk figyelembe venni. 


\section{A minta bemutatása}

A minta nem reprezentatív, hozzáférés-alapú adatgyújtéssel dolgoztunk. Az átlagéletkor 37,4 (sd: 10,68). A nemek arányát tekintve nem kiegyensúlyozott a mintánk, 68,3\%-át alkotják nôk (800 fő), 31,7\%-át férfiak (372 fő). A válaszadók nagy része fơvárosi, illetve városi $(84,3 \%)$, és mintegy $60 \%$-a felsófokú végzettséggel rendelkezik. A munkahely jellégét tekintve a legtöbben állami fenntartású intézményekben, hazai vállalatoknál és multinacionális cégeknél dolgoznak (1. táblázat).

1. táblázat. A minta munkahely jellege szerinti \%-os megoszlása

\begin{tabular}{l|c}
\hline Fenntartó & $\%$ \\
\hline Állami fenntartású intézmények & $26,4 \%$ \\
\hline Hazai vállalatok & $24,5 \%$ \\
\hline Multinacionális cégek & $22,3 \%$ \\
\hline Egyházi fenntartású intézmények & $10,2 \%$ \\
\hline Nonprofit, alapítványi szervezetek & $4,2 \%$ \\
\hline Magánvállalkozás, saját üzlet, föld & $12,3 \%$ \\
\hline
\end{tabular}

A szakmában eltöltött évek száma is változatos képet mutat: van, aki az elsố évét tölti a szakmájában, míg a legmagasabb érték 45 év volt, az átlag 11,06 (sd: 10,39). A munkahelyek száma esetében az átlag 3,9 (sd: 2,53), a legalacsonyabb érték az 1, míg a legmagasabb 30. A minta több mint harmada $(72,2 \%)$ a képzettségének megfelelő munkakörben dolgozik.

\section{A vizsgált változók és a mérốeszközök bemutatása}

Az alábbi kérdőívek magyar változatát oda-vissza fordítással magunk készítettük, a kutatást megelőzôen kisebb mintán kipróbáltuk.

Munkába való bevonódás: A szerzốk szerint a munkába való bevonódás és a kiégés két ellentétes pszichológiai állapot, de konceptuálisan el kell óket választani egymástól, megengedve például, hogy egy nem kiégett dolgozó mutathat alacsony szintú bevonódást is. A sikeresen bevonódott munkavállaló energiával telten és hatékonyan tud bekapcsolódni a munkatevékenységekbe, úgy érzi, jól meg tud küzdeni a munkája kihívásaival (Schaufeli és Bakker, 2004). A 17 itemes Utrecht Work Engagement Scale (Schaufeli, Salanova, Gonzalez-Roma és Bakker, 2002) három dimenzióban méri a bevonódást: energia, elkötelezôdés, belefeledkezés. A válaszokat hatfokú Likert-skálán kell megadni. A skála Cronbach-alfa-értéke kissé magas, de elfogadható: 0,92.

Szakmai elkötelezettség: A szakma iránti elkötelezettség mértékét egy rövid, hétitemes skálával mértük. Blau (1985) eredeti skáláját a (Career Commitment Scale) több verzióban használják (munka, foglalkozás, karrier), mi ezúttal a szakma szót használtuk a skála itemeiben, ötfokú Likert-skálát használtunk (pl. Ha újrakezdhetném, nem ezt a szakmát választanám. Ha nem lenne szükségem pénzre, akkor is ezzel a szakmával foglalkoznék). A skála reliabilitása jó, Cronbach alfa: 0,87. 
Szubjektív pályasikeresség: A skála (Subjective Carreer Success, Turban és Dougherty, 1994) négy itemben, ötfokú Likert-skálával méri több szempont alapján az egyén sikerességérzetét a pályájával kapcsolatban: önmaga szerint, a munkatársakhoz képest, valamint családtagjai, számára fontos személyek megítélése szerint. A válaszokat ötfokú Likert-skálán kell jelölni. A skála Cronbach-alfa-értéke megfelelő: 0,70.

Kilépési szándék: A mérôeszköz öt itemben, ötfokú Likert-skálán méri azt, hogy a válaszadó mérlegeli-e a munkahely elhagyását, tett-e már lépéseket ennek érdekében. Mowday és munkatársai (1979) Turnover Cognition Scale skáláját használtuk. A válaszadók ötfokú Likert-skálán adják meg a válaszaikat. 0,88-as Cronbach-alfa-értékkel a skála megbízhatósága jónak mondható.

További, nem skálákkal mért változók: szakmában eltöltött idô, a jelenlegi munkahelyen letöltött idô, eddigi munkahelyek száma.

\section{EREDMÉNYEK}

A skálák leíró alapstatisztikáit (2. táblázat) vizsgálva az látható, hogy az átlagok egy nagyon kicsivel, de a pozitív irányba mutatnak, a munkába való bevonódás esetében ez egyértelmúbb. A minimum- és maximumértékeket és a szórás értékeit figyelembe véve annyit lehet mondani, hogy a minta kevésbé homogén a változók tekintetében.

2. táblázat. A vizsgálatban használt skálák alapstatisztikái

\begin{tabular}{l|c|c|c|c|c}
\hline Skálák & $\mathbf{N}$ & minimum & maximum & átlag & szórás \\
\hline Szakmai elkötelezettség & 1172 & 1,43 & 5,00 & 3,41 & 0,931 \\
\hline $\begin{array}{l}\text { Munkába való } \\
\text { bevonódás }\end{array}$ & 1172 & 1,18 & 6,00 & 4,05 & 1,16 \\
\hline $\begin{array}{l}\text { Szubjektív } \\
\text { pályasikeresség }\end{array}$ & 1172 & 1,00 & 5,00 & 3,77 & 0,702 \\
\hline Kilépési szándék & 1172 & 1,00 & 5,00 & 2,31 & 1,22 \\
\hline
\end{tabular}

Mivel a mintánk nem reprezentatív, szükségesnek láttuk fố változóink almintánkénti összehasonlítását nem, legmagasabb iskolai végzettség, valamint a munkahely jellege tekintetében. A nemek között egyik esetben sem volt szignifikáns eltérés, a legmagasabb iskolai végzettség esetén a nyolc általános vagy annál alacsonyabb végzettséggel rendelkezôk átlagai voltak minden esetben szignifikánsan eltérôek $\mathrm{p}=0,00$ szinten (szakmai elkötelezettség, munkába való bevonódás, szubjektív pályasikeresség esetében alacsonyabb, a kilépési szándéknál magasabb). Annyit meg kell említeni, hogy nagyon kevés, 22 fố tartozik ebbe a kategóriába. A munkahely jellege szerinti összehasonlításkor a munkába való bevonódásnál találtunk szignifikáns különbséget ( $\mathrm{p}=0,004)$, a multinacionális cégeknél dolgozók jobban bevonódnak a munkatevékenységükbe, mint a saját vállalkozást múködtetôk.

A fenti változókat három idôi változó, a szakmában és a jelenlegi munkahelyen eltöltött idő, az életkor, valamint a munkahelyek száma vonatkozásában vizsgáljuk, ezért érdemes az együtt járásukat is megnézni. Mivel a normalitás nem sérült, ezért Pearson-korrelációval vizsgáltuk meg a feltételezett kapcsolatot. 
A korrelációs elemzés eredményei az idôi tényezók esetében igen gyenge, de szignifikáns kapcsolatot mutatnak. A szakmai elkötelezettség, a munkába való bevonódás és a szubjektív pályasikeresség korrelációs elemzése a várt pozitív együtt járást hozta az idôi tényezôkkel, de nagyon gyenge a kapcsolat. Azonban a munkahelyek száma nem áll összefüggésben a mért változókkal. Az adatok azt mutatják, hogy az idôi tényezôk közül az életkornak és a szakmában eltöltött idônek van erôsebb kapcsolata a vizsgált változóinkkal (3. táblázat).

3. táblázat. A szakmai elkötelezettség, munkába való bevonódás, szubjektív pályasikeresség és a kilépési szándék korrelációi az idôi változókkal

\begin{tabular}{l|c|c|c|c}
\hline & $\begin{array}{c}\text { Szakmai } \\
\text { elkötelezettség }\end{array}$ & $\begin{array}{c}\text { Munkába való } \\
\text { bevonódás }\end{array}$ & $\begin{array}{c}\text { Kilépési } \\
\text { szándék }\end{array}$ & $\begin{array}{c}\text { Szubjektív } \\
\text { pályasikeresség }\end{array}$ \\
\hline $\begin{array}{l}\text { Szakmában eltöltött } \\
\text { idó }\end{array}$ &, $170^{* *}$ &, $189^{* *}$ &,$- 142^{* *}$ &, $153^{* * *}$ \\
\hline $\begin{array}{l}\text { A jelenlegi munkahe- } \\
\text { lyen eltöltött idô }\end{array}$ &, $090^{* *}$ &, $103^{* *}$ &,$- 130^{* *}$ &, $100^{* * *}$ \\
\hline $\begin{array}{l}\text { Eddigi munkahelyek } \\
\text { száma }\end{array}$ &,- 029 &, 018 &, 022 &,- 031 \\
\hline Életkor &, $193^{* *}$ &, $258^{* *}$ &,$- 133^{* *}$ &, $105^{* *}$ \\
\hline
\end{tabular}

Megjegyzés: **-gal jelölt eredmények esetén $\mathrm{p}>0,05$

A 4. táblázat mutatja a vizsgált változóink közötti korrelációk erôsségét. A legerôsebb kapcsolat a szakmai elkötelezettség és a munkába való bevonódás között van, ami összhangban van Brown modelljével (ld. Munkába való bevonódás, Bimrose és Brown, 2019), de szintén erôs a kapcsolat a munkába való bevonódás és a szubjektív pályasikeresség között, viszont ez utóbbi kevésbé erôs kapcsolatban áll a szakmai elkötelezettséggel.

4. táblázat. Az életkor és a szakmai elkötelezettség, munkába való bevonódás, a szubjektív pályasikeresség és munkahelyrôl való kilépési szándék korrelációja

\begin{tabular}{l|c|c|c|c}
\hline & $\begin{array}{c}\text { Szakmai } \\
\text { elkötelezettség }\end{array}$ & $\begin{array}{c}\text { Munkába való } \\
\text { bevonódás }\end{array}$ & $\begin{array}{c}\text { Szubjektív } \\
\text { pályasikeresség }\end{array}$ & $\begin{array}{c}\text { Kilépési } \\
\text { szándék }\end{array}$ \\
\hline $\begin{array}{l}\text { Szakmai elkötelezett- } \\
\text { ség }\end{array}$ & 1 & & & \\
\hline $\begin{array}{l}\text { Munkába való } \\
\text { bevonódás }\end{array}$ &, $625^{* *}$ & 1 & & \\
\hline $\begin{array}{l}\text { Szubjektív pályasike- } \\
\text { resség }\end{array}$ &, $465^{* *}$ &, $615^{* *}$ & 1 & \\
\hline Kilépési szándék &,$- 436^{* *}$ &,$- 450^{* *}$ &,$- 435^{* *}$ & 1 \\
\hline
\end{tabular}

Megjegyzés: **-gal jelölt eredmények esetén $\mathrm{p}>0,05$ 
A kilépési szándékot bejósló változók közötti összefüggés vizsgálata

A modellépítés szempontjából fontos annak elemzése, hogy a kilépési szándékot mennyiben magyarázzák az idôi tényezôk. Lineáris regresszióval ellenôriztük, hogy az életkor, a szakmában eltöltött idô és a jelenlegi munkahelyen eltöltött idố mennyiben magyarázza a kilépési szándékot. Az eredmények szerint a modell nem szignifikáns, vagyis egyik idôi változó sem magyarázza önmagában a kilépési szándékot. Mivel elsôsorban közvetett hatásukat feltételeztük a függó változóra, a következókben lineáris regresszióval vizsgáltuk, hogy a szubjektív pályasikerességet, szakmai elkötelezettséget, valamint a munkába való bevonódást milyen mértékben határozza meg az életkor, a szakmában és a jelenlegi munkahelyen eltöltött idő. Azt találtuk, hogy a szubjektív pályasikerességet, a szakmai elkötelezettséget és a munkába való bevonódást kismértékben, de szignifikánsan magyarázza a szakmában eltöltött idő ( $\beta=0,183, \beta=0,242$; $\mathrm{p}=0,000$, valamint $\beta=0,107)$. Az életkor a munkába való bevonódásra hat szignifikánsan $(\beta=0,167, p=0,00)$, míg a jelenlegi munkahelyen eltöltött időnek nincsen szignifikáns hatása egyik változónkra sem. Feltételezésünk szerint a szubjektív pályasikerességre a munkába való bevonódás és a szakmai elkötelezettség hat, ezért ezt is ellenôriztük. Mindkét változó hatása $\mathrm{p}=0,000$ szinten szignifikáns, a munkába való bevonódás magyarázóereje jóval nagyobb $(\beta=0,32)$, mint a szakmai elkötelezettségé $(\beta=0,11)$.

A regressziós elemzés alapján felállítottunk egy útmodellt, melynek teszteléséhez az AMOS 25 szoftvert használtuk (1. ábra).

A mutatók alapján a modell jó (CMIN/DF: 2,32; CFI: 0,998; PCFI: 0,566; RMSEA: 0,034). Az eredmények szerint az életkor és a szakmában eltöltött idô közvetve, a többi változón keresztül, kismértékben hat a kilépési szándékra. A regressziós elemzéssel megegyezően az életkor a munkába való bevonódást határozza meg szignifikánsan, míg a szakmában eltöltött idő a szakmai elkötelezettséget. Mindkét idôi tényezó mérsékelten magyarázza a szubjektív pályasikerességet, de nincs közvetlen hatásuk a

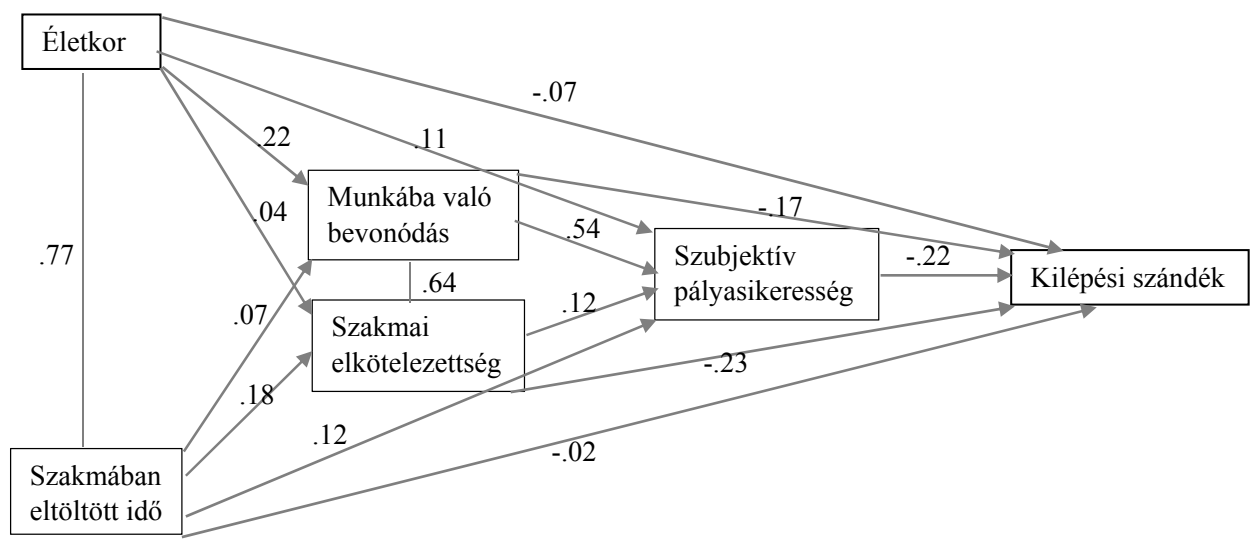

1. ábra. A kilépési szándék bejósló változóinak útmodellje 
kilépési szándékra, vagyis a H1a hipotézisünk, miszerint a szakmában eltöltött idônek és az életkornak közvetett hatása van a munkahelyról való kilépés szándékára, teljesült. A regressziós elemzéshez hasonlóan itt is azt látjuk, hogy a szubjektív pályasikerességet jóval nagyobb mértékben határozza meg a munkába való bevonódás, mint a szakmai elkötelezettség, ez utóbbinak csak csekély hatása van a szubjektív sikerességérzetre. Ugyanakkor a kilépési szándékkal való közvetlen kapcsolatot tekintve a szakmai elkötelezettségnek van valamivel nagyobb magyarázóereje, de a munkába való bevonódásnak is van direkt hatása. Összességében a H1b hipotézis, mely szerint a munkába való bevonódás hatását a szubjektív pályasikeresség mediálja, míg a szakmai elkötelezettség inkább közvetlenül befolyásolja a munkahelyrôl való kilépés szándékát, is igazolódott.

\section{Korcsoportok különbségei}

Ahhoz, hogy a kilépési szándék esetében korosztályi hatást is tetten tudjunk érni, ki kellett alakítani a megfelelô korcsoportokat (5. táblázat). Ehhez az Ifjúságkutatás 2016 fiatalok korcsoportjaira vonatkozó csoportbeosztását vettük alapul, ${ }^{1}$ utána pedig azt az évtizedenkénti beosztást alkalmaztuk, amelyet több kutatás is használ a korcsoportok vizsgálatában, pl. Chopik, Bremner, Johnson és Giasson, 2018; Choong, Keh, Tan és Tan, 2013.

5. táblázat. A korcsoportok beosztása

\begin{tabular}{l|l|l}
\hline 1. korcsoport & $18-24$ év & 130 fó \\
\hline 2. korcsoport & $25-29$ év & 220 fó \\
\hline 3. korcsoport & $30-39$ év & 324 fó \\
\hline 4. korcsoport & $40-49$ év & 321 fó \\
\hline 5. korcsoport & $50-59$ év & 145 fó \\
\hline 6. korcsoport & $60-65$ év & 32 fó \\
\hline
\end{tabular}

\section{A korcsoportok összehasonlitása}

A korcsoportok összehasonlítása összességében azt mutatja, hogy az idôvel nô a szakma iránti elkötelezettség, a munkába való bevonódás, míg a munkahelyrôl való kilépési szándék csökken (2. ábra).

Varianciaanalízissel és Tukey's b post hoc teszttel ellenôriztük a korosztályok közötti különbséget. A szakmai elkötelezettség esetében szignifikáns eltéréseket találtunk korosztályok szerint $(\mathrm{F}=3,59, \mathrm{p}=0,003)$. Az elsô (pályakezdô), második (huszonévesek) és harmadik (harmincasok) korcsoport szignifikánsan alacsonyabb elkötelezettséget mutat, mint az idôsebb korcsoportok. A legmagasabb elkötelezettség szignifikánsan a legidôsebb korosztályra jellemzô. Érdekesség, hogy a második korcsoport átlaga szignifikánsan a legalacsonyabb, ezért a H2a csak részben igazolódott, mivel azt vártuk, hogy az életkorral nô a csoportok szakmai elkötelezettsége.

1 http://mek.oszk.hu/18600/18654/18654.pdf 


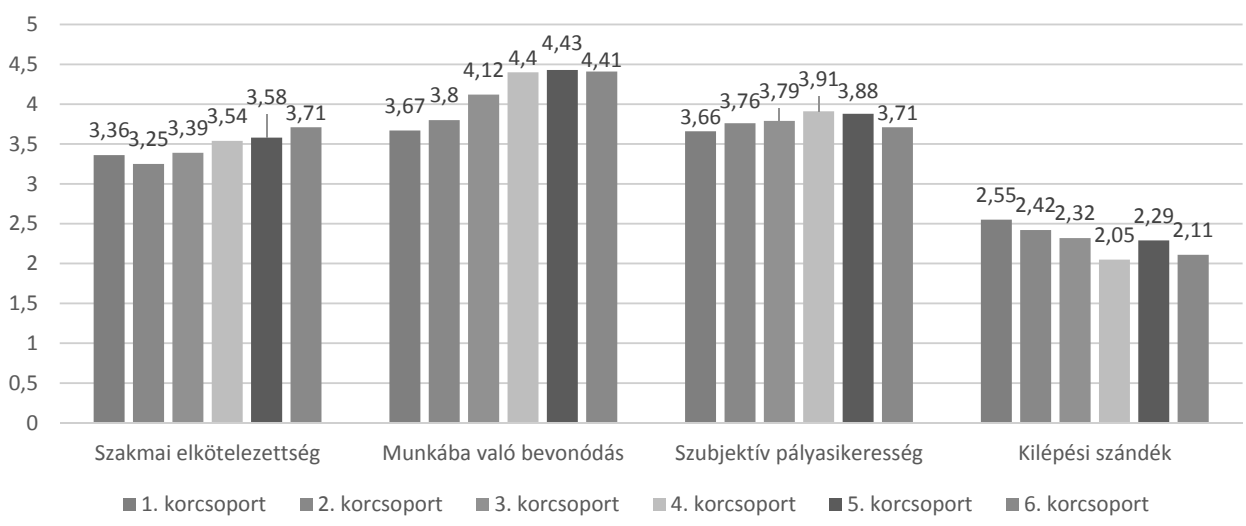

2. ábra. A korcsoportok átlagai a vizsgált változókban

A munkába való bevonódás esetében szignifikáns különbség van a két legfiatalabb, a harmincas és a három idôsebb korosztály között $(\mathrm{F}=10,97, \mathrm{p}=0,00)$. A két legfiatalabb korcsoportra jellemzô legkevésbé a bevonódás, szignifikánsan alacsonyabb a mértéke a többi korcsoporténál. A harmincas korosztály átlaga szignifikánsan magasabb a két fiatalabb, és szignifikánsan alacsonyabb a negyvenes, ötvenes és hatvanas korcsoporténál. A három legidôsebb csoport között nem volt szignifikáns eltérés. Öszszességében a H2b hipotézist csak akkor fogadhatjuk el, ha a fiatal, valamint az idôsebb korcsoportokat összevonjuk.

A szubjektív pályasikeresség változójánál is tapasztalható volt szignifikáns eltérés a korcsoportok szerint $(\mathrm{F}=4,08, \mathrm{p}=0,005)$. A legfiatalabb korosztály értékei szignifikánsan alacsonyabbak, a negyveneseké szignifikánsan magasabbak, mint a többieké. Viszont a legidősebb korcsoport sikerességérzete szignifikánsan alacsonyabb a negyvenes és ötvenes korosztályénál. Ennek alapján az mondható, hogy a H2c hipotézis teljesült, mivel a legfiatalabbak kevésbé érzik magukat sikeresnek a pályájukon, mint az idôsebb korcsoportok.

A kilépési szándék korosztályok szerinti elemzése szintén szignifikáns különbséget mutat $(\mathrm{F}=5,40, \mathrm{p}=0,00)$. A post hoc elemzés alapján a legfiatalabb korosztály szignifikánsan magasabb kilépési szándékot mutat, mint a többi. A 4. (negyvenesek) és 6. korosztály (hatvanasok) értékei szignifikánsan alacsonyabbak a többiekénél, de szignifikáns még az átlagok eltérése a 2. korcsoport (huszonévesek) és a 4. és 6. korcsoport között. Érdekesség, hogy az ötvenesek munkahelyról való kilépési szándéka a harmincasokéval hasonló szintet mutat. Az eredmények tükrében a H2d hipotézis részben teljesült, a munkahelyrôl való kilépés szándéka csökken az idôsebb korosztályok esetében, kivéve az ötvenes korcsoportot.

Izgalmas elemzési szempont a végzettségüknek megfeleló és nem megfelelô munkakörben dolgozók összehasonlítása korcsoportonként, mivel ezzel a szakmával való azonosulásról is képet kaphatunk. Korosztályonként kétmintás t-próbával ellenôriztük a foobb változóink mentén a két csoport különbségeit. A munkába való bevonódás, a szubjektív sikerességérzet és a kilépési szándék esetében az 1-4. korosztálynál szignifi- 
káns a különbség a végzettségüknek megfelelő és nem megfelelô munkakörben dolgozók esetében, az utóbbiak átlagai az alacsonyabbak. Viszont az 5. és 6. korcsoport esetében nem szignifikáns a különbség a két csoport között. A szakmai elkötelezettség esetében minden korosztálynál szignifikánsan alacsonyabb értékeket mutatnak a nem a végzettségüknek megfeleloó munkakörben dolgozók, de a szignifikancia értéke csökken, a 6. korosztálynál a leggyengébb ( $\mathrm{p}=0,001 ; 0,00 ; 0,00 ; 0,005 ; 0,014 ; 0,026)$.

\section{DISZKUSSZIÓ}

A kutatásunk távlati célja a szakmai identitás változásának vizsgálata a pályafutás során. A mostani kutatásunk ennek az elsô lépése, célunk az idói tényezôk hatásának elemzése a pályafutásban, vagyis arra szerettünk volna választ kapni, hogy az idô hatással van-e a szakmai identitás és a vele összefüggésben lévô változók alakulására, a munkatevékenységbe való bevonódásra, a szubjektív pályasikerességre és a munkahelyrôl való kilépés szándékára. Vizsgálatunkban ezeket a változókat a szakmában eltöltött idô, a jelenlegi munkahelyen eltöltött idô, valamint az életkor vonatkozásában elemeztük. A korrelációs és regressziós elemzések alapján az mondható, hogy az idôi változók közül a szakmában eltöltött idônek és az életkornak van valamennyi szerepe a szakmai identitás alakulásában, de a munkahelyen eltöltött időé elhanyagolható, ami leginkább a munkahelyrôl való kilépés szándékával hozható kapcsolatba. Ez azt támasztja alá, hogy a szakmai identitás valóban hosszabb távú elkötelezôdést jelent, és az életkorral az elkötelezettség mélyül.

Az elemzésünkben egy útmodellt teszteltünk, hogy ellenôrizzük az idôi tényezôk hatását a szakmához való viszonyulásra, valamint a munkahelyrôl való kilépési szándékra. A modell szerint az életkornak és a szakmában eltöltött idônek inkább a szakmai elkötelezettségre és a munkába való bevonódásra van valamekkora hatása, a szubjektív sikerességérzetre már kisebb, a kilépési szándékra pedig nem hatnak közvetlenül. Az eredmények alapján összességében az mondható, hogy az idôi tényezôk a munkába való bevonódás, a szakmai elkötelezettség és a szubjektív pályasikeresség változóin keresztül közvetve hatnak a munkahelyrôl való kilépési szándékra. Másrészrôl ezek az idői hatások igazolják a szakmával való azonosulás és a bevonódás folytonos természetét.

A munkába való bevonódásnak nagy hatása van a szubjektív sikerességérzetre, és azon keresztül hat inkább a kilépési szándékra, míg a szakmai elkötelezettség inkább közvetlenül hat a kilépési szándékra, mint a sikerességérzeten keresztül, azaz a szakmai elkötelezettség protektív faktor is lehet munkahelyi, munkával kapcsolatos nehézségek esetén. Az egyén szakmai csoporttagsága, a szakmai csoporttal való azonosulása nemcsak azt segíti elô, hogy a munkatevékenységét jobban élvezze, és egyúttal növekedjen a sikerességérzete, hanem ha ez valamilyen oknál fogva akadályba ütközik, az érzelmi involváltságának köszönhetôen kisebb valószínúséggel lépjen ki a munkahelyérôl. Azonban meg kell jegyezni, hogy ez a hatás is mérsékelt, vagyis a munkahelyrôl való kilépési szándékot még egyéb, a modellünkben nem szereplô tényezók befolyásolják.

A korcsoportok különbségei elemzésének is az volt a célja, hogy feltárjuk az idô szerepét a pálya alakulásában a vizsgált változóink segítségével. Összességében azt felté- 
teleztük, hogy a legfiatalabb korcsoport mutatja a legalacsonyabb értékeket, a munkahelyrôl való kilépés szándéka kivételével, ahol a legmagasabbat, és minél idôsebb egy korosztály, úgy változnak lineárisan az értékek, mivel a tapasztalatok, a kompetenciák fejlődése elôsegíti a szakmához és a munkatevékenységhez való pozitív viszonyulást. Ez nem minden esetben bizonyult helytállónak. Az eredmények szerint a 18-24 éves korosztály szakmával való azonosulása szinte azonos szinten van a 30-39 évesekével, és náluk szignifikánsan alacsonyabb a 25-29 éves korosztályé. Ha megpróbáljuk értelmezni a mi eredményeinket, akkor a pályakezdők kezdeti lelkesedését feltételezhetjük, ami után a „kijózanodás”, a realitással való szembenézés csökkentheti az elkötelezettség mértékét. Valószínúleg újra erósebben tud azonosulni a szakmájával az, aki a választott pályáján marad. Ezt az összefüggést jó lenne további kutatással vizsgálni. Meg kell említeni a linearitás kapcsán, hogy a magas szintú bevonódáshoz, a munkában tapasztalt flow-élményhez bizonyos fokú érettség, szakmai felkészültség, megfeleló kompetenciák szükségesek. Az idô múlásával a munkavállalók olyan tudásra és gyakorlati tapasztalatra tehetnek szert, ami lehetôvé teszi, hogy megéljék kompetenciáik kibontakozását. A munkába való bevonódás faktorainak elemzésével teljesebb képet kaphatunk a korosztályok különbségeirôl ezen a területen.

A szubjektív pályasikeresség esetében is a várt eredményt kaptuk: a legfiatalabbak érzik magukat a legkevésbé sikeresnek. Viszont azt is láthatjuk, hogy a hatvanasok sikerességérzete alacsonyabb a negyvenes és ötvenes korcsoporténál. Ez az eredmény a Super-féle pályaívhez illeszkedik. A munkahelyrôl való kilépés szándéka esetében érdekes eredményt kaptuk. A legfiatalabbaknak szignifikánsan magasabb a kilépési szándéka, és ez fokozatosan csökken a 40-49 éves korosztályig, viszont az 50-59 éves korosztálynál ez az érték a harmincasok szintjére emelkedik. Ez annak az eredménynek a fényében érdekes leginkább, hogy a munkába való bevonódás és a szakmai elkötelezettség esetében ezzel ellentétes tendenciát tapasztaltunk ennél a korosztálynál. Ennek okait érdemes lenne egy további, más módszertanú kutatással feltárni.

A végzettségnek megfelelố és nem megfelelô munkakörben dolgozók korcsoportonkénti összehasonlítása arra enged következtetni, hogy olyan mértékben hat a szakmai szocializáció elsô, a képzés során megvalósuló szakasza a szakmai elkötelezettségre, hogy az a pálya végéig érezteti hatását. Ugyanakkor a sikerességérzet és a munkatevékenység örömében az idôsebb korosztályoknál már eltûnik a különbség, vagyis ezeket a tényezóket más tényezők befolyásolják.

A demográfiai változók mentén képzett alcsoportok összehasonlításával egy izgalmas eredményt kaptunk, miszerint a multinacionális cégeknél dolgozók munkába való bevonódása szignifikánsan magasabb, mint a saját céget, vállalkozást vezetôké. Ennek okait keresve gondolhatunk többek között a munkafeladatok mennyiségére és jellegére, a vállalkozás fenntartásával járó terhekre vagy a felelôsség és a vezetôi szerep kérdésére. Ezt egy további vizsgálatban érdemes lenne körüljárni.

Összegezve, az eredményeink nem támasztják alá az idối tényezók közvetlen hatását a munkahelyrôl való kilépési szándék esetében, vagyis önmagában nincs jelentôsége annak a kilépés vonatkozásában, ki hány évet tölt a munkahelyén. Ezzel szemben az életkornak és a szakmában eltöltött időnek van, még ha mérsékelt hatása is, a szakmai identitásra. Ezzel azt tudjuk igazolni, hogy az azonosulás, elkötelezôdés alakulásában a folytonosságnak van valamennyi szerepe. 
A vizsgálat legnagyobb korlátja az, hogy keresztmetszeti vizsgálatot végeztünk, korcsoportokat hasonlítottunk össze, holott a változást inkább folyamatában lenne szerencsés megragadni. A korcsoportok kialakítása mesterséges, ezért az eredmények értelmezésekor ezt figyelembe kell venni. A másik korlátozó tényezô a minta kiegyensúlyozatlansága, mivel a nôk, fiatalok és felsôfokú végzettségúek felülreprezentáltak. Bár az almintánkénti összehasonlítás kevés szignifikáns különbséget mutatott, az eredmények nem általánosíthatók a magyar munkavállalók teljes csoportjára. Az eredmények alapján viszont azt mondhatjuk, hogy más módszertannal érdemes tovább folytatni a téma kutatását.

\section{IRODALOM}

Ashforth, B. E., \& Saks, A. M. (1995). Work-role transitions: A longitudinal examination of the Nicholson model. Journal of Occupational and Organizational Psychology, 68(2), 157-161.

Bakker, A. B., \& Schaufeli, W. B. (2008): Positive organizational behavior: Engaged employees in flourishing organizations. Journal of Organizational Behavior, 29(2), 147-154.

Bimrose, F., \& Brown, A. (2019). Professional identity transformation: supporting career and employment practitioners at a distance. British Journal of Guidance \& Counselling, 47(6), $757-769$.

Blau, G. (1985). The measurement and prediction of career commitment. Journal of Occupational Psychology, 58(4), 277-288.

Blau, G. J., \& Boal, K. B. (1987): Conceptualizing How Job Involvement and Organizational Commitment Affect Turnover and Absenteeism. The Academy of Management Review, 12(2), 288-300.

Blustein, D. L. (2013). The psychology of working: A new perspective for a new era. In Blustein, D. L. (Ed), The Oxford handbook of the psychology of working (pp. 3-18.). Oxford: Oxford University Press.

Bodnár, G., \& Takács, I. (2006). Szocializáció. In Juhász M., Takács I. (szerk.), Pszichológia. Budapest: Typotex Kiadó.

Chang, W. J. A., Wang, Y. S., \& Huang, T. C. (2013). Work design-related antecedents of turnover intention: A multilevel approach. Human Resource Management, 52(1), 1-26.

Chen, I. H., Brown, R., Bowers, B. J., \& Chang, W. J. (2015). Work-to-family conflict as a mediator of the relationship between job satisfaction and turnover intention. JAN, 71(10), 2350-2363.

Choong, Y. O., Keh, C. G., Tan, Y. T., \& Tan, C. E. (2013). Impacts of Demographic Antecedents toward Turnover Intention amongst Academic Staff in Malaysian Private Universities. Australian Journal of Basic and Applied Sciences, 7(6), 46-54.

Chopik, W. J., Bremner, R. H., Johnson, D. J., \& Giasson, H. L. (2018). Age Differences in Age Perceptions and Developmental Transitions. Front Psychol, 9(67). Letöltve: 2020. 01. 31-én: www.frontiersin.org/articles/10.3389/fpsyg.2018.00067/full,.

Colarelli, S. M., \& Bishop, R. C. (1990). Career Commitment. Group \& Organization Studies, 15(2), 158-176.

Deaux, K., Reid, A., Mizrahi, K., \& Ethier, K. A. (1995). Parameters of Social Identity. Journal of Personality and Social Psychology, 68(2), 280-291.

Ellemers, N., Kortekaas, P., \& Ouwerkerk, J. W. (1999). Self-categorisation, commitment to the group and group self-esteem as related but distinct aspects of social identity. European Journal of Social Psychology, 29(2-3), 371-389. 
Ferraro, H. S., Prussia, G., \& Mehrotra, S. (2018). The impact of age norms on career transition intentions. Career Development International, 23(2), 212-229.

Gibson, D. (2003). Developing the Professional Self-Concept: Role Model Construals in Early, Middle, and Late Career Stages. Organization Science, 14(5), 591-610.

Hartmann, N. N., \& Rutherford, B. N. (2015). Psychological contract breach's antecedents and outcomes in salespeople: The roles of psychological climate, job attitudes, and turnover intention. Industrial Marketing Management, 51, 158-170.

Hartung, P. J. (2013). The life-span, life-space theory of careers. In Brown, S. D., \& Lent, R. W., (Eds), Career development and counseling: Putting Theory and Research to Work (pp. 83-114.). Hoboken: Wiley.

Haslam, S. A., Jetten, J., Postmes, T., \& Haslam, C. (2009). Social Identity, Health and WellBeing: An Emerging Agenda for Applied Psychology. Applied Psychology: An International Review, 58(1), 1-23.

Haslam, C., Holme, A., Haslam, S. A., Iyer, A., Jetten, J., \& Williams, W. H. (2008). Maintaining group memberships: Social identity continuity predicts well-being after stroke. Neuropsychological Rehabilitation, 18(5-6), 671-691.

Holland, J. L. (1997). Making vocational choices: A theory of vocational personalities and work environments. 3rd edition. Psychological Assessment Resources.

Ibarra, H. (1999). Provisional selves: Experimenting with image and identity in professional adaptation. Administrative Science Quarterly, 44(4), 764-791.

Katz, I. M., Rudolph, C. W., \& Zacher, H. (2019). Age and career commitment: Meta analytic tests of competing linear versus curvilinear relationships. Journal of Vocational Behavior, 112, 396-416.

Khapova, S. N., Arthur, M. B., Wilderom, C. P. M., \& Svensson, J. S. (2007). Professional identity as the key to career change intention. Career Development International, 12(7), 584-595.

Kiss P. (2012). Büszkeség, önértékelés és elkötelezôdés: egy irányba mutatnak a csoportközi viselkedés alapvetô erối? In Fülöp, M., \& Szabó, É. (szerk.), A pszichológia mint társadalomtudomány (pp. 353-370.). Budapest: ELTE Eötvös Kiadó.

Lent, R. W., \& Brown, S. D. (2013). Understanding and Facilitating Career Development in the 21st Century. In Brown, S. D., Lent, R. W. (Eds). Career Development and Counseling (pp. 1-28.). 2nd edition. Hoboken: Wiley.

Luthans, F., Avolio, B. J., Avey, J. B., \& Norman, S. M. (2007). Positive Psychological Capital: Measurement and Relationship with Performance and Satisfaction. Personnel Psychology, $60(3), 541-572$.

Maslach, C., \& Leiter, M. P. (1997). The truth about burnout: How organizations cause personal stress and what to do about it. San Francisco: Jossey-Bass.

Mowday, R. T., Steers, R. M., \& Porter, L. W. (1979). The measurement of organizational commitment. Journal of Vocational Behavior, 14(2), 224-247.

Nagy Ádám (szerk.) (2016). Margón kívül, magyar ifjúság kutatás 2016. Excenter kutatócsoport. Letöltve: 2020. 09. 11-én: http://mek.oszk.hu/18600/18654/18654.pdf

Nauta, M. M. (2013). Holland's theory of vocational choice and adjustment. In Brown, S. D., \& Lent, R. W. (Eds), Career Development and Counseling. Putting Theory and Research to Work (pp. 55-82.). Hoboken: Wiley.

Pataki, F. (2004). Érzelem és identitás. Budapest: Új Mandátum Könyvkiadó.

Patton, W., \& McMahon, M. (2014). Career Development and Systems Theory. 3rd edition. Rotterdam-Boston-Taipei: Sense Publishers.

Ritoók, M. (2008). Pályafejlôdés - Pályafejlődési tanácsadás. Budapest: ELTE Eötvös Kiadó.

Saks, A. M. (2006). Antecedents and consequences of employee engagement. Journal of Managerial Psychology, 21(7), 600-619. 
Savickas, M. L. (2013). Career Construction Theory and Practice. In Brown, S. D., Lent, R. W. (Eds). Career Development and Counselling (pp. 111-124.). 2nd edition. Hoboken: Wiley.

Savickas, M. L. (2012). Life design: A paradigm for career intervention in the 21st century. Journal of Counseling \& Development, 90(1), 13-19.

Schaufeli, W. B. (2012). The measurement of work engagement. In Sinclair, R. R., Wang, M., Tetrick, L. E. (Eds), Research methods in occupational health psychology: Measurement, design, and data analysis (pp. 138-153.). New York: Routledge.

Schaufeli, W. B., \& Bakker, A. B. (2004). Job demands, job resources, and their relationship with burnout and engagement: A multi-sample study. Journal of Organizational Behavior, 25(3), 293-315.

Schaufeli, W. B., Salanova, M., Gonzalez-Roma, V., \& Bakker, A. B. (2002). The measurement of engagement and burnout and: A confirmative analytic approach. Journal of Happiness Studies, 3(1), 71-92.

Sullivan, S. E., \& Crocitto, M. (2007). The Developmental Theories: A Critical Examination of Their Continuing Impact on Career Research. In Gunz, H., \& Peiperl, M. (Eds), Handbook of Career Studies (pp. 283-309.). Thousand Oaks: Sage Publications.

Super, D. E. (1980). A Life-Span, Life-Space Approach to Career Developement. Journal of Vocational Behavior, 16(3), 282-298.

Tajfel, H. (1981). Human groups and social categories. Cambridge: Cambridge University Press.

Turban, D. B., \& Dougherty, T. W. (1994). Role of Protégé Personality in Receipt of Mentoring and Career Success. Academy of Management Journal, 37(3), 688-702.

Turner, J. C. (1987). Rediscovering the social group: A self-categorization theory. Oxford: Blackwell.

Twenge, J. M., Campbell, S. M., Hoffman, B. J., \& Lance, C. E. (2010). Generational Differences in Work Values: Leisure and Extrinsic Values Increasing, Social and Intrinsic Values Decreasing. Journal of Management, 36(5), 1117-1142.

Yates, J. (2017). A social identity approach to career development: possible selves and prototypical occupational identities. Doctoral dissertation. University of East London. Letöltve 2020. 09. 10-én: https://repository.uel.ac.uk/item/84v8x.

Wehmeyer, M. L., Nota, L., Soresi, S., Shogren, K. A., Morningstar, M. E., Ferrari, L., et al. (2019). A Crisis in Career Development: Life Designing and Implications for Transition. Career Development and Transition for Exceptional Individuals, 42(3), 179-187. 


\title{
THE RELATIONSHIP BETWEEN PROFESSIONAL COMMITMENT AND TURNOVER COGNITIONS IN THE LIGHT OF CAREER PROGRESS
}

\author{
KOLTÓI, LILLA
}

Background: Recent career paths are typically fragmented, consisting of sequences, so redefinition of work values, work attitudes and professional identity is necessary (Wehmeyer et al., 2019; Ashforth \& Saks, 1995). On the other hand, professional identity and commitment is of long perspective, and more stable factor (Colarelli \& Bishop, 1990), so change of workplace will more moderately affect it, if the individual stays I his profession.

Purpose: The goal is to explore the impact of time factors on attitudes to profession and work. We would like to explore that in what extent the career relevant factors such as professional commitment, work engagement, and subjective career are influenced by age, years spent in profession and at recent workplace, and how these constructs relate to turnover cognitions.

Methods: Employees with active permanent employment were examined in an online survey $(N=1172)$. Hypothesis were tested by path analysis and comparing age groups.

Results: According to our results, time factors do not influence turnover cognitions in a direct way, just through variables of work engagement, professional commitment and subjective career success, while they affect the professional commitment and work engagement directly. The results of generational analysis reveal that the degree of work engagement and professional commitment increases with age, but the degree of the willingness of turnover decreases until the age of 40s, while it increases in the oldest group to the level of age of 30 s.

Keywords: turnover, professional commitment, work engagement, social identity theory

A cikk a Creative Commons Attribution 4.0 International License (https://creativecommons. org/licenses/by/4.0) feltételei szerint publikált Open Access közlemény, melynek szellemében a cikk bármilyen médiumban szabadon felhasználható, megosztható és újraközölhetô, feltéve, hogy az eredeti szerzố és a közlés helye, illetve a CC License linkje és az esetlegesen végrehajtott módosítások feltüntetésre kerülnek. (SID_1) 